\title{
Exchange rates and immigration policy
}

Adrian J. Shin

Correspondence: Adrian.Shin@ colorado.edu

University of Colorado Boulder, 333

UCB, Boulder, CO 80309, USA

\section{Springer Open}

\begin{abstract}
What explains cross-national and temporal variations in migrant rights? This article argues that policymakers implement more exclusionary or inclusive policies toward migrants in response to exchange-rate fluctuations. Since exchange rates affect the real value of remittances, exchange-rate depreciation of the host state's currency makes migration less valuable for existing and potential migrants, while exchangerate appreciation increases the degree of migrant pressure on the host state by doing the opposite. This well-documented relationship between exchange rate valuation and migration movements affects how host country governments craft immigration policy. Under exchange-rate depreciation, policymakers will implement more inclusive policies to deter the "exit" of migrants and maintain a stable supply of labor. Under exchange-rate appreciation, increased migration pressures heighten public anxiety over immigration in the host country, in turn causing policymakers to restrict further immigration by implementing more exclusionary policies. Consistent with the argument, the empirical results show that the purchasing-power-parity (PPP) currency values of migrants' home countries are positively correlated with more pro-migrant policies in host countries.
\end{abstract}

"A survey by Britain's largest Polish-speaking radio station at the end of last year reported that almost 40 percent of migrant Polish workers would seriously consider returning home if the exchange rate fell to four zlotys to the pound." (Financial Times, 25 May 2008; Taylor 2008).

\section{Introduction}

As of 2017, the number of international migrants is estimated to be 258 million or roughly $3.4 \%$ of the world population. Nearly $57 \%$ of these migrants live in the developed world, representing approximately $14.1 \%$ of the total population among high-income countries. $^{1}$ In response, policymakers of migrant-hosting states have implemented "behind-the-border" immigration policies stipulating the extent of rights and benefits to which migrants are entitled. Unlike immigration quotas and other entry-specific forms of

${ }^{1}$ Data from United Nations Department of Economic and Social Affairs (2017), International Migration Report, 2017.

(c) The Author(s). 2021 Open Access This article is licensed under a Creative Commons Attribution 4.0 International License, which permits use, sharing, adaptation, distribution and reproduction in any medium or format, as long as you give appropriate credit to the original author(s) and the source, provide a link to the Creative Commons licence, and indicate if changes were made. The images or other third party material in this article are included in the article's Creative Commons licence, unless indicated otherwise in a credit line to the material. If material is not included in the article's Creative Commons licence and your intended use is not permitted by statutory regulation or exceeds the permitted use, you will need to obtain permission directly from the copyright holder. To view a copy of this licence, visit http://creativecommons.org/licenses/by/4.0/. 
immigration policy, these policies directly target immigrants who already reside in the host state. More importantly, behind-the-border policies have proved instrumental not only in attracting or deflecting new migrants, but also in incentivizing or discouraging existing migrants to remain in the country (e.g., Fitzgerald et al. 2014).

It is well-documented that pro-migrant policies can be politically costly for policymakers owing to public concerns about labor-market competition (Borjas 2003; Hatton and Williamson 2005, 2007), perceptions of migrants as a strain on fiscal resources (Hanson et al. 2007; Neuman 1993; Razin et al. 2011), or views of immigration as posing a cultural threat (Freeman 1995; Zolberg 1989; Hainmueller and Hiscox 2007, 2010). Yet, why do some countries pursue policies more favorable to immigrants while other countries engage in more restrictive policies?

To explain the variation in migrant rights, the majority of the comparative immigration policy literature tends to focus on the domestic political factors of host countries, such as political parties, the size of the immigrant electorate, and the role of labor unions (Haus 2002; Watts 2002; Givens and Luedtke 2005; Koopmans et al. 2012). In addition, because immigrants are often desired as an alternative source of labor, policymakers sometimes choose to liberalize certain aspects of immigration policy when economic factors render the host country an unattractive destination for migrants (Nikolova 2017; Peters 2019; Timmer and Williamson 1998). These domestic forces are certainly important in explaining immigration-policy variation across countries and over time. However, only a small group of scholars have examined how the dynamics of the global economy shape policy responses to immigration (e.g., Peters 2014, 2015, 2017).

This article argues that policymakers implement more exclusionary or inclusive policies toward migrants in response to fluctuations between their currencies and those of their major migrant-sending countries. While high wages clearly attract migrants (Massey et al. 1993; Abella 1995; Hanson and Spilimbergo 1999; Breunig et al. 2012; Ortega and Peri 2013), migrants are also vulnerable to exchange-rate devaluation since they send a large portion of income to their families back home as remittances (Clemens 2011; Hanson and Spilimbergo 1999; Mishra and Spilimbergo 2011; Singer 2010; Yang 2008). Many migrants therefore prefer to work in countries where they can enjoy highly valued currencies since this increases the real value of remittances. Conversely, when exchange-rate shocks negatively affect migrants' real income earned in the host country, migrants may consider returning home or moving to other destinations. For these reasons, exchange-rate depreciation is likely to deter future immigration (Hanson and Spilimbergo 1999; Mishra and Spilimbergo 2011) while exchange-rate appreciation increases migration pressures on host states through both formal and informal channels.

Considering the importance of exchange rates in understanding cross-border migration patterns, persistent changes in exchange-rate movements can shape policymakers' responses toward existing and prospective immigrants. On the one hand, exchange-rate depreciation and subsequent rises in return migration force businesses to pay higher wages or seek additional labor in the short term (Mishra and Spilimbergo 2011). In efforts to deter this threat of "exit" and maintain a stable supply of labor, policymakers can implement inclusive policies by offering political rights and other types of social security to migrants. An example of inclusive policies is to implement integration policies 
that allow immediate family members to enter the host state. This would eliminate the need to send remittances altogether while encouraging migrants to seek long-term residence. Combined with more inclusive social and cultural rights, these "integration" policies increase the likelihood that migrants remain in host states (Ortega and Peri 2013; Fitzgerald et al. 2014; Alarian and Goodman 2017), and eventually reduce their dependence on remittances and their sensitivity to exchange-rate fluctuations.

On the other hand, exchange-rate appreciation increases the volume of immigration, which fuels voter anxiety over immigration. This induces policymakers to restrict the number of immigrants through entry barriers as well as exclusionary policies. These measures include reducing or eliminating the extent to which migrants are entitled to social provisions and legal privileges. In addition, states may implement more aggressive policies, such as border apprehensions and deportation raids to remove undocumented immigrants and discourage potential migrants.

One observable implication based on the dynamics described above is a positive relationship between the value of sending states' exchange rates and the extent to which migrants are entitled to inclusive policies in the host state. I evaluate this claim using a cross-sectional dataset with the available data on migrant rights in ten European liberal democracies between 1980 and 2008. I also introduce a new country-level measurethe migrant-weighted exchange rate (MRER) - which I construct by summing each country's bilateral nominal exchange rates weighted by migrant shares and adjusted for the effects of inflation. This measure offers a new method for capturing the importance of exchange-rate fluctuations as it relates to total remittance flows. The results support that the host state's treatment of immigration depends on the exchange rate of that country relative to its largest migrant-sending countries. This finding illustrates the connection between global economic shocks and changes in immigration policy.

\section{Exchange-rate shocks and immigration policy}

To influence migration patterns, states can restrict or expand the scope of social entitlement to immigrants, including eligibility for social welfare benefits, citizenship requirements, access to housing, unemployment protection, and deportation criteria. Several works demonstrate how the expansion of these rights affect immigration patterns. Looking at the "tightness" of immigration policy, Ortega and Peri (2013) find that unfavorable immigration policies, including immigration quotas and national policies toward existing immigrants, reduce immigration inflows. Others find favorable immigration policies, such as dual citizenship policies, increase immigration flows by allowing migrants to retain rights and benefits granted in their native countries (Fitzgerald et al. 2014; Alarian and Goodman 2017).

Owing to the credible exit option held by migrants (Hirschman 1970; Gelbach 2006), behind-the-border policies are likely to change in response to adverse economic conditions that disproportionately affect foreign workers in the host state. Temporal trends in exchange rates are an important consideration of migrant workers since they affect the real value of remittances sent to their home countries. In particular, negative exchange shocks-or when the currency of the destination country depreciates-decrease the real value of migrant remittances. For instance, the weak U.S. dollar eroded the peso value of Filipino workers' salaries by 20 to $25 \%$ since 2000 (Landingin 2007). This leads not only to a direct loss in real income, but also puts limits on how much a 
household can invest in education since families often employ their children immediately in the workforce to compensate for lost earnings in the near term (Yang and Martinez 2006; Yang 2008). If depreciation in the exchange rate persists as a trend, existing migrant workers may be inclined to leave host countries while potential migrant workers are deterred from emigrating to that country in the first place (Hanson and Spilimbergo 1999; Mishra and Spilimbergo 2011).

Although not all migrants are economically-driven, the large volume of remittancesboth in absolute terms and relative to other sources of capital for developing economies (Kapur 2005; Yang and Choi 2007)—suggests that the exit of migrant workers resulting from exchange-rate depreciation can be substantial. Several empirical studies demonstrate this point. Using the example of Filipino migration during the Asian financial crisis, Yang (2006) finds that a $10 \%$ depreciation of the Philippine peso led to a $1.4 \%$ reduction in annual return migration.

Conversely, the appreciation of the host country's currency can be attractive to migrant workers and their families. When Mexico devalued the peso against the U.S. dollar in 1994, many voters in the U.S. worried that the depreciating Mexican peso would increase undocumented immigration into the U.S. Hanson and Spilimbergo (1999) find that the appreciation of the U.S. dollar relative to the Mexican peso spurred an increase in the volume of illegal migration across the U.S.-Mexico border. ${ }^{2}$ In response, the Clinton administration implemented a series of reforms, including the Illegal Immigration Reform and Immigration Responsibility Act of 1996. While the bill was designed to strengthen existing immigration laws, it also increased the penalties for unauthorized immigration by monitoring overstayed visas, imposing criminal charges for fraudulent papers, and deportations for felonies and misdemeanors. The increasing volume of illegal immigration, and the subsequent policy responses, contributed to the rise of "the raid mentality" in the U.S. which sought to invoke extreme measures against undocumented immigrants (Tirman 2015).

The Clinton administration's immigration reforms made deportation a highly plausible reality for many; immigrants saw an increased number of causes and actions that could make them more deportable. Compared to the number of immigrant removals during the George H.W. Bush administration $(141,326)$, the Clinton administration increased the number of deportations by 728,320 , totaling 869,646 - most of which occurred before the dot-com bubble (Nowrasteh 2019). As the Mexican peso remained substantially devalued until 2004, the George W. Bush administration-coming into office in the wake of the dot-com crash-deported over 2 million undocumented individuals, an increase of over a million from the previous administration (Nowrasteh 2019). The Mexican peso crisis illustrates the long-term consequences of currency devaluation in shaping migration patterns at the U.S.-Mexico border and the subsequent immigration crackdown implemented by the U.S. government.

The U.S.-Mexico case illustrates that an excessive immigration surplus can be politically costly for policymakers of advanced democracies where anti-immigrant sentiment is prevalent among their native citizens. However, the loss of migrant workers can be

\footnotetext{
${ }^{2}$ Table A3 of the Additional file 1 shows a negative and statistically significant correlation between appreciation in a country's real effective exchange rate (REER) and emigration flows. In these models, I regress emigration flows (logged) on annual changes in a country's real effective exchange rate from 1964 to 2008. Annual changes in a sending country's currency value exhibit a negative correlation with emigration.
} 
also detrimental to the political survival of incumbents since policymakers must also respond to powerful domestic interests in favor of immigration. The pro-immigration coalition typically includes firms relying on foreign labor-both unskilled and skilledwho require an adequate supply of labor to remain competitive. ${ }^{3}$ With a diminished supply of foreign labor, firms incur a variety of losses, including short-term wage increases and high transaction costs associated with seeking new workers (Aydemir and Borjas 2007; Mishra 2007; Mishra and Spilimbergo 2011). For instance, Aydemir and Borjas (2007) find that a 10\% decrease in the labor supply caused by emigration is associated with a 3 to $4 \%$ increase in wages. These rising costs of labor can jeopardize the competitiveness and essential operation of firms. As pro-immigration interests often have political access to legislators (e.g., Facchini et al. 2011), the adverse effects of currency depreciation on labor costs can pressure governments to take corrective policy measures to attract and retain migrant workers.

Therefore, the variation in migrant-related policies should be connected to how exchange-rate shocks affect migration incentives. Indeed, Western liberal democracies exhibit a wide variation in immigration policy provisions, in terms of labor market mobility, the right to family reunion, and political participation. In most liberal democracies, basic rights to life, liberty, and property are guaranteed for all individuals regardless of their citizenship status. For instance, Title VII of the Civil Rights Act of 1964 prohibits discrimination in employment on the basis of sex, race, color, national origin, and religion in the U.S. The Supreme Court ruled that Title VII applies to noncitizens in Espinoza vs. Farah Manufacturing Company. Furthermore, the European Convention on Human Rights (ECHR) implies that "all migrant workers admitted for employment in Council of Europe member states are covered its provisions irrespective of their country of origin" (Cholewinski 2004). Yet, the courts and governments have also maintained that non-citizen immigrants are not entitled to the same rights of citizens. For instance, migrants may not be fully eligible for state resources for education, welfare benefits, or employment-related protection, depending on the countries where they reside.

It is important to note that while immigration policies should most strongly alter incentives for permanent migration, such policies are also likely to influence temporary migrants who are particularly affected by exchange-rate fluctuations. As Fitzgerald et al. (2014) show, short-term bilateral migration flows are quite responsive to changes in immigration policy restrictiveness and citizenship policies. In addition, the distinction between temporary and permanent migration is not as clear cut in practice as it is in theory. Historical examples of guest-worker programs illustrate this point. Even though the rights of guest workers to residency, employment, and social benefits were time-restrictive, many guest workers in Europe during the 1970s and braceros in the U.S. during the 1960s decided to remain in their host countries permanently (Reichert and Massey 1980, 1982). In fact, following the expiration of European guest-worker programs during the economic turmoil of the 1970s, foreign populations rapidly increased in guest-worker destinations with many workers bringing their families (Reichert and Massey 1982, p. 4). Thus, when migrants decide whether to remain

${ }^{3}$ See Freeman 1995; Money 1997; Facchini et al. 2011; Peters 2014, 2015, 2017. 
in host countries, they take into account the host country's immigration regime since it has important ramifications for their long-term status.

To summarize the argument, negative exchange rate shocks decrease incentives to migrate to a country while also increasing incentives for existing migrants to leave the country. This is worrisome for business interests relying on foreign labor since a diminished supply of migrant workers increases the costs of labor. In order to placate concerns of labor-intensive firms then, policymakers pursue policies that improve the rights and treatment of immigrants and foreign residents. In this sense, domestic policies directed toward immigrants can be attributed to policymakers' self-interested desires to retain and attract migrants, precisely when exchange-rate depreciation diminishes the incentives to migrate to the country. At the same time, policymakers also worry about potential electoral punishment by voters when exchange-rate appreciation increases the volume of immigration into their countries. Taken together, I propose the following hypothesis:

Hypothesis: A decline (an increase) in the migrant-receiving country's currency value relative to migrant-sending countries' currencies leads to more expansive (more restrictive) policies toward immigrants in the migrant-receiving country.

\section{Empirical analysis}

To examine the determinants of migrant rights, I use a cross-sectional dataset of ten Western European countries in 1980, 1990, 2002, and 2008. Data on national policies concerning migrant rights and other accommodative policies are scarce. For the main results, I use data from Koopmans et al. (2012). This dataset does not have annual observations but provides a broad coverage of migrant rights in ten advanced industrial democracies where immigration flows are both large and politically salient. For recent years, the percentage of immigrants in these countries constitutes roughly $10 \%$ on average although there is some variation across countries and over time. For instance, one out of five individuals in Switzerland is an immigrant-the highest percentage in the sample. Although Norway's immigrant network was relatively small in the beginning of the 1960s, the country has experienced steady flows of immigrants over the past 50 years, reaching a $10 \%$ immigrant-to-population ratio in the $2000 \mathrm{~s}$.

It is still important to be aware of the limits of the empirical analysis. Specifically, cross-sectional data limits the ability to analyze the effect of exchange fluctuations on within-country changes in immigration policy over time. Thus, the main empirical analysis instead aims to explain cross-national variation in immigration policy-although some temporal variation is present in the analysis. For robustness checks, I later estimate models using alternative measures of immigration policy-including from Peters and Shin (2021), and the Immigration Polices in Comparison (IMPIC) project-which are shown in Table 3 . These alternative measures are available annually but are less refined in terms of policy specificity.

For the key independent variable, I introduce a new country-level measure labeled as the migrant-weighted real exchange rate (MRER). I construct this measure using data on the ratio of purchasing power parity (PPP) conversion factor to market exchange rate, weighted by bilateral migration stocks (World Bank 2014). The ratio is also known as the national price level, indicating how many dollars one needs in order to buy a 
dollar's worth of goods in the country of interest (i.e., a migrant-sending country) as compared to the U.S. This measure makes it easy to standardize and compare various migrant groups' values of returning home and to interpret the coefficient of MRER. The MRER is formulated as follows:

$$
M R E R_{i t}=\sum_{j=1}^{n} M_{t}^{j i} \frac{P P P / e_{j t}}{P P P / e_{i t}}
$$

where $M R E R_{i t}$ is the migration-weighted real exchange rate (averaged across all years since $t-1)$ of country $i$ for time $t,{ }^{4} M_{t}^{j i}$ is the number of foreign-born nationals from country $j$ as the percentage of the total immigrant stock in country $i$ in year $t, P P P / e_{j t}$ is the PPP conversion factor to market exchange rate ratio of country $j$ as compared to the U.S. for time $t$, and $P P P / e_{i t}$ is the PPP conversion factor to market exchange rate ratio of country $i$ as compared to the U.S. for time $t$. Therefore, $\frac{P P P / e_{i t}}{P P / e_{i t}}$ indicates the PPP conversion factor to market exchange rate ratio of country $j$ as compared to country $i$. In short, the migration-weighted real exchange rate is the sum of bilateral nominal exchange rates weighted by migrant shares and adjusted for the effects of inflation. MRER within the sample ranges from 0.339 to 0.848 with a mean of 0.597 , indicating that migrants tend to emigrate from countries where the cost of living is relatively inexpensive in terms of the PPP conversion factor and the market exchange rate. ${ }^{5}$

Figure 1 illustrates the MRER trend for each immigrant destination. For instance, the UK's MRER shows a sharp rise during the global financial crisis. This trend is indicative of the British pound's sudden depreciation in 2008-a higher value of MRER-relative to the currencies of the UK's largest migrant-sending countries, such as Poland and India. From the beginning of 2007 to the beginning of 2011, the pound-rupee (GBP/INR) exchange rate decreased from 87.1 to 69.3. Over the same period, the pound-zloty (GBP/ PLN) exchange rate declined from 5.7 to $4.6 .^{6}$ It is also worth noting that similar dynamics appear to be unfolding in the UK today. The post-Brexit depreciation of the British pound has caused many Polish immigrants to question their stay in the country. As one Polish immigrant explains, " ... the worst thing is that we had already been thinking about going back, and the decline of the pound means we lost a lot of money."

The U.S. exchange rate relationship with major migrant-sending countries-particularly Mexico-can also be observed in Fig. 1. The sudden dip in the United States' MRER - the appreciation of U.S. dollar-in the early 1980s coincides with the Latin American debt crisis, when the currencies of Mexico and other major Latin American migrant-sending countries depreciated drastically. Similar to the UK, the U.S. MRER trended slightly upward around 2008. This change, however, was much more moderate relative to the UK, which can be attributed to the persistent strength of the U.S. dollar throughout the global financial crisis.

\footnotetext{
${ }^{4}$ Since bilateral migration stocks are only available at decade intervals, I use 1980, 1990, 2000, 2008 (interpolated) migration weights for 1980, 1990, 2002, and 2008 exchange rates, respectively.

${ }^{5}$ In Tables A12 and A13 of the Additional file 1, I substitute in delta variables for MRER that measure absolute and percentage changes in $\mathrm{MRER}_{\text {it }}$ between time points.

${ }^{6}$ Exchange-rate data comes from the International Monetary Fund's Exchange Rate Archives.

7"Poles see dwindling economic benefit of living in Britain." Reuters. Anna Koper and Barteczko. September $12,2017$.
} 


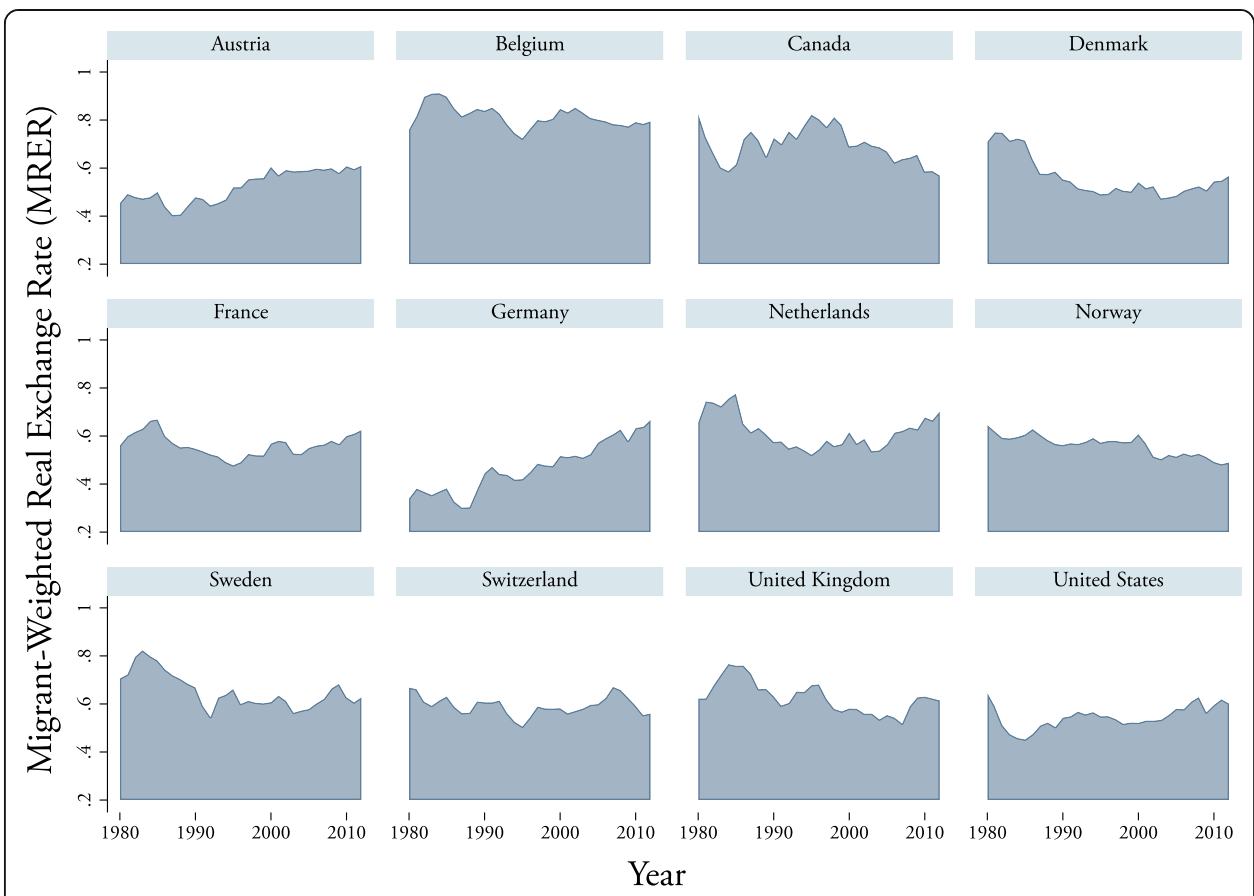

Fig. 1 MRER Trends in High-Income Immigrant Destinations

Considering that the dataset is not yearly, a potential problem is that movements in MRER are "smoothed" out over time-that is, short-term exchange rate fluctuations between time $t$ and time $t+1$ will not be observed if short-term appreciation (depreciation) in MRER is offset by short-term depreciation (appreciation) in MRER within the same time frame. Without annual data on migrant rights, the analysis is restricted to looking at how long-term overall trends in MRER affect migration policies. Nonetheless, it is important to be aware of how this limitation may affect the statistical results.

To the extent that this problem is present, smoothing out MRER is likely to bias against finding support for the argument. For instance, if gradual appreciation in MRER is suddenly offset by steep depreciation at the end of the time period, one might still expect immigration policy to shift in a more open direction. This is because legislation is more likely to respond to long-term trends rather than short-term exchange rate fluctuations. However, given that no long-term change in MRER would be observed in this scenario, any changes in migration policy could not be attributed to MRER. In other words, if significant changes in MRER are being averaged out within each time frame, we would observe that changes in migration policy occur when there is no observed overall change in MRER, thus increasing the chance of Type II (false negative) error.

Data for other independent variables come from various sources. Data on the vote share of right-wing populist parties are from Swank (2014)'s Comparative Parties Dataset, primarily based on the classifications in Castles and Mair (1984). Data on immigrant vote shares are drawn from Koopmans et al. (2012). Economic variables are collected from various sources including the Organization for Economic Cooperation and Development (OECD), the World Bank, and the Bank for International Settlements. Since I do not have annual data for the dependent variable (i.e., migrant rights), 
I use the average values of independent variables between observed values of migrant rights unless noted otherwise. For instance, when estimating the dependent variable in year 1990, I use the average values of MRER and all control variables from 1980 to 1989.8

I estimate all models using an ordinary least square (OLS) regression with panelcorrected errors (Beck and Katz 1995). All models include year fixed effects to control for time trends and other global-level factors, such as international human rights norms or global commodity price shocks. Some models include the lagged dependent variable or country fixed effects, but not both given the short time panel $(T=4)$ and the resulting Nickell bias (Nickell 1981). The functional form of a panel data model is as follows:

$$
Y_{i t}=\beta_{0}+\beta_{1} \text { MRER }_{i t}+\sum_{k=2}^{n}\left(\beta_{k} \text { Control Variable }(k-1), i t\right)+\text { Year Fixed Effects }+\varepsilon_{i t}
$$

where $Y_{i t}$ is a measure of migrant rights from Koopmans et al. (2012). ${ }^{9}$

The hypothesis predicts that as the value of a sending state's currency increases (decreases), migrants gain (lose) more benefits and rights in receiving states. I control for a list of factors that are associated with MRER and may also relate to the dependent variable. I first include the migration-weighted GDP per capita of sending states to account for the level of economic development in migrants' home countries. Poor countries tend to have lower currency values when adjusted for inflation and the consumer price index. Since return migration is less attractive for migrants originally from impoverished countries, policymakers may discriminate against migrants from these countries when responding to exchange rate fluctuations.

Next, I control for a variety of domestic factors, such as the population share of immigrants who can vote (i.e., immigrant electorate), trade union density, and the vote share of right-wing populist parties. While labor unions had historically opposed immigrants (Goldin 1994), many trade unions in the U.S. and Europe have chosen to include immigrants as members by opposing certain restrictive immigration policy measures in the late twentieth century (Haus 2002; Watts 2002). Therefore, I expect the coefficient of the union variable to be positive. I also include the right-wing populist party vote share as a proxy for nativism with an expectation that its coefficient is negative. I expect the coefficient of immigrant electorate to be positive since policymakers are more likely to accommodate immigrant interests when they are more electorally accountable to immigrants. I include these variables because they may be correlated with MRER and can potentially explain variation in the dependent variable. Both a higher degree of trade union density and a larger size of the immigrant electorate can attract migrants from high-MRER countries and may have a causal effect on the dependent variable. Similarly, a higher right-wing populist vote share may reduce net immigration from high-MRER countries as migrants with exit options may not tolerate rising antiimmigrant sentiment (e.g., Fitzgerald et al. 2014).

\footnotetext{
${ }^{8}$ Similarly, I use 1970-1979, 1990-2001, and 2002-2007 for 1980, 2002, and 2008, respectively. For alternative dependent variables that have annual observations, I use annual MRER values.

${ }^{9}$ Koopmans et al. (2012) provide indicators on (1) Individual Equality dimension; (2) Nationality Acquisition; (3) Expulsion; (4) Marriage Migration; (4) Anti-Discrimination; (5) Political Rights; (6) Cultural Dimension; and (7) Cultural and Religious Rights. Detailed descriptions of these indicators are provided in Table A2 in the Additional file 1.
} 
As a first-cut analysis, I test the hypothesis with Individual Equality Dimension as the dependent variable. Koopmans et al. (2012) constructs this weighted variable of migrant rights by averaging Nationality Acquisition (double-weighted), Expulsion, Marriage Migration, Access to Public Service Employment, Anti-discrimination, and Political Rights. Following a discussion of these results, I also provide additional tests for these individual indicators in the Additional file 1.

The results for Individual Equality Dimension are reported in Table 1. Model (1) includes MRER as the only explanatory variable, with year fixed effects. Additional controls are then added in Models (2) through (5) in Table 1 and Models (6) through (8) in Table 2 to demonstrate the robustness of the results. Consistent with the hypothesis, the sending state's exchange rate level is positively associated with the extension of migrant rights in all models. In Model (2), a .1-unit increase of MRER leads to a 0.157unit increase in Individual Equality Dimension $(p<0.01)$. This is a substantively important change given that the dependent variable ranges from -0.69 to 0.57 . The evidence for the effect of GDP per capita on the dependent variable is mixed across the models. The coefficient of sending states' GDP per capita is consistently positive, but only reaches statistical significance in Model (5).

There is also some evidence that the size of the immigrant electorate is positively correlated with the dependent variable. Since the dependent variable includes the ease of acquiring citizenship, this relationship may not necessarily be causal. When migrants can acquire citizenship easily, the immigrant electorate should naturally expand. Trade union memberships are also positively associated with migrant rights. As previously mentioned, trade unions in Europe have grown weary of social dumping through which migrants often are paid lower wages than native workers. Instead of spending their

Table 1 Individual equality dimension (1980-2008)

\begin{tabular}{|c|c|c|c|c|c|}
\hline & (1) & (2) & (3) & (4) & (5) \\
\hline $\begin{array}{l}\text { Individual Equality } \\
\text { Dimension }_{t-1}\end{array}$ & & & & $0.774^{\mathrm{a}}(0.080)$ & \\
\hline MRER $_{i j}$ & $1.697^{\mathrm{a}}(0.470)$ & $1.566^{\mathrm{a}}(0.433)$ & $1.046^{\mathrm{b}}(0.319)$ & $0.457^{d}(0.254)$ & $0.797^{\complement}(0.322)$ \\
\hline $\begin{array}{l}\text { GDP per Capita } \\
\text { (US\$ in Thousands) }\end{array}$ & & $0.007(0.012)$ & $0.009(0.018)$ & $0.010(0.013)$ & $0.038^{\mathrm{a}}(0.009)$ \\
\hline Immigrant Electorate $_{i}$ & & & $0.035^{\mathrm{a}}(0.008)$ & $0.005(0.008)$ & $0.031^{c}(0.016)$ \\
\hline Trade Union Density $i$ & & & $0.005^{d}(0.003)$ & $-0.001(0.001)$ & $0.000(0.003)$ \\
\hline $\begin{array}{l}\text { Right-Wing Populist } \\
\text { Vote Share }_{i}\end{array}$ & & & $-0.026^{\mathrm{C}}(0.011)$ & $-0.007^{d}(0.004)$ & $0.002(0.004)$ \\
\hline Year 1990 & $0.085^{\mathrm{a}}(0.000)$ & $0.076^{\mathrm{a}}(0.016)$ & $0.048^{d}(0.029)$ & & $-0.013(0.023)$ \\
\hline Year 2002 & $0.294^{\mathrm{a}}(0.015)$ & $0.257^{\mathrm{a}}(0.060)$ & $0.274^{c}(0.124)$ & $0.087^{d}(0.051)$ & $-0.055(0.056)$ \\
\hline Year 2008 & $0.266^{\mathrm{a}}(0.013)$ & $0.187(0.133)$ & $0.164(0.225)$ & $-0.128(0.123)$ & $-0.374^{b}(0.116)$ \\
\hline Country Fixed Effects & & & & & $\checkmark$ \\
\hline Year Fixed Effects & $\checkmark$ & $\checkmark$ & $\checkmark$ & $\checkmark$ & $\checkmark$ \\
\hline Observations & 40 & 40 & 40 & 30 & 40 \\
\hline Countries & 10 & 10 & 10 & 10 & 10 \\
\hline$R^{2}$ & 0.304 & 0.306 & 0.529 & 0.912 & 0.941 \\
\hline
\end{tabular}

Ordinary least square analysis of Individual Equality Dimension, measuring the extent to which migrants are entitled to various rights other than cultural and religious rights. The constant is included, but not reported in the table. Panelcorrected standard errors are in parentheses. ${ }^{a},{ }^{b},{ }^{c}$, and ${ }^{d}$ indicate statistical significance levels of .1, 1, 5, and 10 percent, respectively 
Table 2 Individual equality dimension robustness checks (1980-2008)

\begin{tabular}{|c|c|c|c|}
\hline & (6) & (7) & (8) \\
\hline MRER $_{i j}$ & $0.374^{\complement}(0.161)$ & $0.883^{c}(0.352)$ & $0.359^{d}(0.206)$ \\
\hline GDP per Capita (US\$ in Thousands) & $0.083^{\mathrm{a}}(0.018)$ & $0.046^{\mathrm{a}}(0.013)$ & $0.078^{\mathrm{a}}(0.016)$ \\
\hline Immigrant Electorate $_{i}$ & $0.070^{\mathrm{a}}(0.020)$ & $0.027(0.018)$ & $0.057(0.037)$ \\
\hline Trade Union Density $i$ & $0.008^{\mathrm{C}}(0.004)$ & $-0.003(0.004)$ & $0.010^{c}(0.005)$ \\
\hline Right-Wing Populist Vote Share ${ }_{i}$ & $0.003(0.005)$ & $0.002(0.004)$ & $0.004(0.005)$ \\
\hline Polity Score ${ }_{j}$ & $0.125^{\mathrm{a}}(0.016)$ & & $0.115^{\mathrm{a}}(0.018)$ \\
\hline GDP per Capita (US\$ in Thousands) & $0.003(0.008)$ & & $0.008(0.011)$ \\
\hline GDP Growthi & $-3.675(3.418)$ & & $-3.902(3.642)$ \\
\hline Real Effective Exchange Rate ${ }_{i}$ & $0.000(0.003)$ & & $0.001(0.004)$ \\
\hline Immigration Policy ${ }_{i}$ & $0.032(0.072)$ & & $0.027(0.070)$ \\
\hline Ln (Population) ${ }_{i}$ & $0.647(1.079)$ & & $0.862(1.396)$ \\
\hline Population Share of Immigrants ${ }_{i}$ & $7.406^{\mathrm{a}}(1.368)$ & & $7.993^{\mathrm{a}}(1.575)$ \\
\hline Colonial Migration $\%$ from $j$ in $i$ & & $-0.474^{d}(0.252)$ & $-0.010(0.427)$ \\
\hline Linguistic Proximity between $i$ and $j$ & & $-0.057(0.101)$ & $0.155(0.248)$ \\
\hline Country Fixed Effects & $\checkmark$ & $\checkmark$ & $\checkmark$ \\
\hline Year Fixed Effects & $\checkmark$ & $\checkmark$ & $\checkmark$ \\
\hline Observations & 40 & 40 & 40 \\
\hline Countries & 10 & 10 & 10 \\
\hline$R^{2}$ & 0.976 & 0.943 & 0.977 \\
\hline
\end{tabular}

Ordinary least square analysis of the Individual Equality Dimension, measuring the extent to which migrants are entitled to various rights other than cultural and religious rights. The constant and year fixed effects are included, but not reported in the table. Panel-corrected standard errors are in parentheses. ${ }^{a} c_{\text {, }}$ and ${ }^{d}$ indicate statistical significance levels of $.1,5$, and $10 \%$, respectively

political capital on entry restrictions, trade unions have become proponents of migrant rights to combat employers' tendency to take advantage of migrant workers.

In Model (4), I include the lagged dependent variable to address the possibility that policies of migrant rights tend to persist over time within each country. The coefficients of many of the controls are no longer statistically distinguishable from zero, and the sign of the coefficient for Trade Union Density reverses, possibly because these variables are largely time-invariant (Achen 2000). Nevertheless, the coefficient of MRER is still positive and statistically significant at the 0.10 level. Model (5) includes countryfixed effects while excluding the lagged dependent variable. The results from Model (5) still lend support for the argument that a higher value of MRER is positively associated with the expansion of migrant rights. Across the models, we see that year fixed effects have positive, statistically significant coefficients, indicating that migrant rights have improved over time compared to the baseline year, 1980.

Table 2 provides robustness checks for Individual Equality Dimension. First, I include the migration-weighted polity score of sending states in Model (6). Model (6) also controls for the economic characteristics of host states, including GDP per capita, GDP growth, the natural log of population, and the population share of immigrants. I also added the real effective exchange rate (REER) of host states to Model (6). Similar to MRER, REER is the average of a country's currency relative to the currencies of its major trading partners, adjusted for the effects of inflation. There is some evidence that import-competing firms and exporters lobby for compensatory policies when high 
exchange rates reduce their competitiveness (Broz and Werfel 2014). The results indicate no evidence of a correlation between REER and the dependent variable. In addition, there is no significant correlation between MRER and REER (0.185) because they are weighted by bilateral migration stocks and trade flows, respectively.

I next control for the immigration policy variable concerning entry restrictions in Model (6). ${ }^{10}$ There has been much debate about whether countries with more restrictive entry policies provide their immigrants with more rights or vice versa (Ruhs 2013). Since MRER can potentially affect entry restrictions by shaping migration patterns, including the immigration policy variable in the regression provides an additional robustness check. For instance, countries that grant more rights to migrants may have selective immigration policies at the border. These entry restrictions may attract only migrants from countries that either are wealthy or have higher values of MRER. Controlling for immigration entry criteria addresses this endogeneity concern.

In Model (7), I include other characteristics of sending states, including the share of migrants from former colonies and the linguistic proximity between receiving and sending states' official languages. For instance, former colonies of host states may have unobservable factors that shape both migration flows into their former colonial powers and how host states treat their former colonial subjects through the provision of migrant rights. In Model (8), I include the control variables of both Models (6) and (7). Across all models, the coefficient of MRER remains positive and statistically distinguishable from zero within the 95 - or $90 \%$ confidence interval.

Finally, I use three modified measures of MRER to replicate the results of Table 1. First, Table A11 of the Additional file 1 presents the results estimating the relationship between migrant rights and MRER volatility as an additional covariate. In Table A12, I difference the MRER variable to regress Individual Equality Dimension on changes in MRER. In Table A13, I use percentage changes in MRER as the explanatory variable. These results lend support for the hypothesis in the model specifications that include country fixed effects. Detailed discussion on these results can be found in the Additional file 1 .

\section{Alternative dependent variables}

In this section, I present results using alternative measures of the dependent variable. I examine the correlations between $\mathrm{MRER}_{i j}$ and immigrant rights as measured and coded by Peters and Shin (2021) and the Immigration Policies in Comparison (IMPIC) Project. These two alternative dependent variables provide adequate robustness checks because they provide comprehensive yearly time coverage across countries despite their lack of details on policy dimensions. From the Peters and Shin (2021) and the IMPIC datasets, I take variables that are close proxies for the Individual Equality Dimension. Table 3 reports the results.

Model (9) reports the results using the data from Peters and Shin (2021). The dependent variable in this model is a continuous measure of the policy scope of immigrant rights. A score of 1 indicates few immigrant rights, and a score of 5 indicates parity with citizens. At 1 , immigrants are confined to the job they have and must leave the state if they leave the job. They have no political rights, no rights to public goods, and

${ }^{10}$ The immigration policy variable comes from Peters (2015) and Shin (2019). 
Table 3 Immigrant rights - alternative dependent measures

\begin{tabular}{|c|c|c|c|}
\hline & $\begin{array}{l}\text { (9) } \\
\text { Peters and Shin }\end{array}$ & $\begin{array}{l}\text { (10) } \\
\text { IMPIC (OLS) }\end{array}$ & $\begin{array}{l}\text { (11) } \\
\text { IMPIC (Ordered Probit) }\end{array}$ \\
\hline MRER $_{\mathrm{ij}}$ & $0.548^{\mathrm{a}}(0.166)$ & $0.643^{\mathrm{a}}(0.081)$ & $3.968^{d}(2.188)$ \\
\hline GDP per Capita (US\$ in Thousands) & $0.021^{c}(0.010)$ & $0.011^{b}(0.003)$ & $0.050(0.041)$ \\
\hline Trade Union Density ${ }_{i}$ & $0.005^{\mathrm{a}}(0.001)$ & $-0.001(0.001)$ & $0.000(0.012)$ \\
\hline Right Wing Populist Vote Share ${ }_{i}$ & $-0.018^{\mathrm{b}}(0.006)$ & $-0.006^{\mathrm{a}}(0.001)$ & $-0.065(0.047)$ \\
\hline Year Fixed Effects & $\checkmark$ & $\checkmark$ & $\checkmark$ \\
\hline Observations & 533 & 526 & 526 \\
\hline Countries & 17 & 17 & 17 \\
\hline$R^{2}$ or Pseudo $R^{2}$ & 0.096 & 0.278 & 0.261 \\
\hline
\end{tabular}

Ordinary least square analysis of Immigrant Rights in Models (9) and (10) and ordered probit analysis in Model (11). Model (9) shows results using the immigrant rights variable in the Peters and Shin (2021), and Models (10) and (11) show results using the IMPIC indicator of whether migrants can vote in a national election. In Models (10) and (11), the dependent variable was recoded so that more migrant rights are coded high. The constant is included, but not reported in the table. Panel-corrected standard errors are in parentheses for Models (9) and (10), and clustered standard errors on country are in parentheses for Model (11). ${ }^{\mathrm{a}}, \mathrm{b}, \mathrm{c}$, and ${ }^{\mathrm{d}}$ indicate statistical significance levels of .1, 1, 5, and $10 \%$, respectively

cannot own property. At 5, immigrants have the same access to these rights and goods as natives do. I find that higher levels of $\mathrm{MRER}_{i j}$ are positively associated with more expansive migrant rights in a country.

Models (10) and (11) use data from the IMPIC Project. The IMPIC Project contains panel data on migrant voting rights from 1980 to 2010. For these models, I use a measure of migrant voting rights in national elections. The measure lies on a scale of $0-1$, where 0 indicates no right, .5 indicates a discriminatory right, and 1 indicates a universal right. ${ }^{11}$ Model (10) uses an OLS regression with panel-corrected standard errors, and Model (11) uses a more precise ordered probit model. Like the other measures, I find a positive correlation between $\mathrm{MRER}_{i j}$ and the right to vote. This implies that as $\mathrm{MRER}_{i j}$ increases, there is an increased probability of migrants gaining a universal right to vote in national elections. For instance, using estimates from Model (11), a 1 SD increase in $\mathrm{MRER}_{i j}$ from its mean is associated with an approximately 15 percentagepoint increase in the likelihood of the right to vote. ${ }^{12}$

Aside from Peters and Shin (2021) and the IMPIC Project, other datasets on migrant rights include the Determinants of International Migration (DEMIG) Policy Data, the Migrant Integration Policy Index (MIPEX), and data from Ruhs (2013). DEMIG, MIPEX, and Ruhs (2013) present valuable data but are not adequate data sources for operationalizing the hypothesis of this article. For DEMIG, the unit of analysis is a change in a country's migration policy in a given year, noting how the policy shifted. This means that the dataset does not tell us anything about the level of migrant rights but only changes of these values over time. The MIPEX dataset is also problematic since it does not provide a large number of observations. MIPEX's most comprehensive dataset includes only years 2013 and 2014.

\footnotetext{
${ }^{11}$ This is recoded from the original data, where a 0 indicates a universal right, and 1 indicates no right. It is recoded so that it can be interpreted similarly as the other models, where more inclusive migrant rights are coded higher values.

${ }^{12}$ This estimate is obtained when holding all other covariates at their means.
} 
Lastly, hypothesis testing for the argument of this article requires a country-year unit of analysis. Neither DEMIG nor Ruhs (2013)'s dataset meets this requirement. Moreover, these datasets cannot be easily configured into a panel format. While DEMIG looks solely at annual changes in migration policy rather than levels, the Ruhs (2013) dataset has a unit of analysis at the program level, assessing only how certain programs have affected migrant rights. For these reasons, both of these alternative measures cannot provide useful robustness checks.

\section{Discussion and conclusion}

The argument of this article relies on the assumption that migrants send remittances to their home countries. This assumption may not be plausible for immigrants who have settled permanently in host states and immigrants who have become citizens. Although I have used the number of foreign-born individuals to calculate MRER, the pool of foreign-born individuals includes both those who immigrated several decades ago and others who have come more recently. Although this complicates the empirical analysis, the following justification may alleviate some of this concern. First, mass migration to and within Europe is relatively new, starting with guest-worker programs after the Second World War. Given the time coverage of the sample, immigrants and their countries of origins used to calculate MRER reflect these growing immigration communities. Second, existing migrant communities facilitate new migration inflows from their home countries by reducing transaction costs (e.g., Massey et al. 1993). In this regard, the migrant stock variable represents transnational networks through which migration patterns shift in response to exchange-rate fluctuations.

This article makes two important contributions to the political economy of migration. First, it emphasizes the importance of exchange rates in studying the politics of migration. Changes in exchange-rate levels have significant consequences on migrants' living standards, their migration decisions, and labor market outcomes when their families back home are heavily dependent on remittances as a source of income. While the role of remittances has recently experienced a surge of scholarly attention, the most important price for remittances - the exchange rate level-has been often overlooked in the political economy literature. Given the economic significance of migrant workers in liberal democracies, the political and economic ramifications of remittances and relevant exchange rates deserve careful attention in studying national policy making. This article is the first attempt to assess the policy implications of exchange-rate levels with respect to domestic migration policy.

Second, this article is part of a growing literature on how the dynamics of the global economy shape immigration policies (Peters 2015, 2017; Shin 2017, 2019). As multinational corporations depend on their manufacturing plants across the globe and foreign markets, labor market stability has become one of the most important objectives in international business. As unexpected exchange rate shocks lead to changes in wages and create labor shortages, business interests have been proactive to demand corrective immigration policies. Considering the growing scholarly interest in the politics of migration within the framework of international political economy, this article offers a promising venue for future research to study the factor mobility of goods, capital, or people in relation to one another.

\section{Supplementary Information}

The online version contains supplementary material available at https://doi.org/10.1186/s40878-021-00228-2.

Additional file 1. Descriptive Statistics and Tables. 


\section{Acknowledgements}

The author would like to thank William Clark, Robert Franzese, John Jackson, David Leblang, Margaret Peters, David Singer, and Dean Yang for helpful comments. I also thank Brendan Connell and Sam Moya for their excellent research assistance.

\section{Author's contributions}

Adrian J. Shin is the sole author of this manuscript and has been responsible for all theoretical and empirical contributions of this manuscript. The author read and approved the final manuscript.

\section{Funding}

This material is based upon work supported by the National Science Foundation Graduate Student Research Fellowship under Grant No. DGE 0718128 . Any opinions, findings, and conclusions or recommendations expressed in this material are those of the author and do not necessarily reflect the views of the National Science

Foundation. Publication of this article was funded by the University of Colorado Boulder Libraries Open Access Fund.

\section{Availability of data and materials}

The datasets used and/or analysed during the current study are available from the corresponding author on reasonable request.

\section{Competing interests}

The author declares that they have no competing interests.

Received: 29 January 2020 Accepted: 4 February 2021

Published online: 26 May 2021

\section{References}

Abella, M. I. (1995). Asian labour migration: Past, present, future. ASEAN Economic Bulletin, 12(2), 125-135.

Achen, C. (2000, July). Why lagged dependent variables can suppress the explanatory power of other independent variables [Paper presentation]. The annual meeting of the political methodology section of the American Political Science Association, Los Angeles, USA

Alarian, H. M., \& Goodman, S. W. (2017). Dual citizenship allowance and migration flow: An origin story. Comparative Political Studies, 50(1), 133-167.

Aydemir, A., \& Borjas, G. J. (2007). Cross-country variation in the impact of international migration: Canada, Mexico, and the United States. Journal of the European Economic Association, 5(4), 663-708.

Beck, N., \& Katz, J. N. (1995). What to do (and not to do) with time series cross-sectional data. American Political Science Review, 89(3), 634-647.

Borjas, G. J. (2003). The labor demand curve is downward sloping: Reexamining the impact of immigration on the labor market. The Quarterly Journal of Economics, 118(4), 1335-1374. https://doi.org/10.1162/003355303322552810.

Breunig, C., Cao, X., \& Luedtke, A. (2012). Global migration and political regime type: A democratic disadvantage. British Journal of Political Science, 32(4), 825-854.

Broz, J. L., \& Werfel, S. H. (2014). Exchange rates and industry demands for trade protection. International Organization, 68(2), $393-416$.

Castles, F. G., \& Mair, P. (1984). Left-right political scales: Some 'expert' judgements. European Journal of Political Research, 12(1), 147-157.

Cholewinski, R. (2004). The legal status of migrants admitted for employment. Strasbourg: Council of European Publishing

Clemens, M. A. (2011). Economics and emigration: Trillion-dollar bills on the sidewalk? Journal of Economic Perspectives, 25(3), 83-106.

Facchini, G., Mayda, A. M., \& Mishra, P. (2011). Do interest groups affect US immigration policy? Journal of International Economics, 85(1), 114-128.

Fitzgerald, J., Leblang, D., \& Teets, J. (2014). Defying the law of gravity: Political economy of international migration. World Politics, 66(3), 406

Freeman, G. P. (1995). Modes of immigration politics in liberal democratic states. International Migration Review, 29(4), 881-902.

Gelbach, S. (2006). A formal model of exit and voice. Rationality and Society, 18(4), 395-418.

Givens, T., \& Luedtke, A. (2005). European immigration policies in comparative perspective: Issue salience, partisanship and immigrant rights. Comparative European Politics, 3, 1-22.

Goldin, C. (1994). The political economy of immigration restriction in the United States, 1890-1921. In C. Goldin, \& G. D. Libecap (Eds.), The regulated economy: A historical approach to political economy (pp. 223-257). Chicago: University of Chicago Press.

Hainmueller, J., \& Hiscox, M. J. (2007). Educated preferences: Explaining attitudes toward immigration in Europe. International Organization, 61(2), 399-442.

Hainmueller, J., \& Hiscox, M. J. (2010). Attitudes toward highly-skilled and low-skilled immigration: Evidence from a survey experiment. American Political Science Review, 104(1), 61-84.

Hanson, G. H., Scheve, K., \& Slaughter, M. J. (2007). Public finance and individual preferences over globalization strategies. Economics and Politics, 19(1), 1-33.

Hanson, H. G., \& Spilimbergo, A. (1999). Illegal immigration, border enforcement, and relative wages: Evidence from apprehensions at the US-Mexico border. The American Economic Review, 89(1), 73-92.

Hatton, T. J., \& Williamson, J. G. (2005). Global migration and the world economy. Cambridge: MIT Press.

Hatton, T. J., \& Williamson, J. G. (2007). A dual policy paradox: Why have trade and immigration policies always differed in labor scarce economies? In A. M. Taylor, T. J. Hatton, \& K. H. O'Rourke (Eds.), The new comparative economic history: Essays in honor of Jeffrey $G$. Williamson. Cambridge: MIT Press. 
Haus, L. (2002). Unions, immigration, and internationalization: New challenges and changing coalitions in the United States and France. New York: Palgrave Macmillan.

Hirschman, A. O. (1970). Exit, voice, and loyalty: Responses to decline in firms, organizations, and states (vol. 25). Cambridge: Harvard University Press.

Kapur, D. (2005). Remittances: The new development mantra? In S. Maimbo, \& D. Ratha (Eds.), Remittances: Development impact and future prospects. Washington, DC: The World Bank.

Koopmans, R., Michalowski, I., \& Waibel, S. (2012). Citizenship rights for immigrants: National political processes and crossnational convergence in Western Europe, 1980-2008. American Journal of Sociology, 117(4), 1202-1245.

Landingin, R. (2007, November 16). Exchange rate keep Filipinos from working abroad. The Financial Times. https://www.ft. com/content/00eb2c88-93cf-11dc-acd0-0000779fd2ac

Massey, D. S., Arango, J., Hugo, G., Kouaouci, A., Pellegrio, A., \& Taylor, J. E. (1993). Theories of international migration: A review and appraisal. Population and Development Review, 19(3), 431-466.

Mishra, P. (2007). Emigration and wages in source countries: Evidence from Mexico. Journal of Development Economics, 82(1), 180-199.

Mishra, P., \& Spilimbergo, A. (2011). Exchange rates and wages in an integrated world. American Economic Journal: Macroeconomics, 3(4), 53-84.

Money, J. (1997). No vacancy: The political geography of immigration control in the advanced industrial countries. International Organization, 51(4), 685-720.

Neuman, G. L. (1993). The lost century of American immigration law (1776-1875). Columbia Law Review, 93(8), 1833-1901.

Nickell, S. J. (1981). Biases in dynamic models with fixed effects. Econometrica, 49, 1417-1426.

Nikolova, E. (2017). Destined for democracy? Labour market and political change in colonial British America. British Journal of Political Science, 47(1), 19-45.

Nowrasteh, A. (2019, September 15). Deportation rates in historical perspective. Cato Institute. https:/www.cato.org/blog/ deportation-rates-historical-perspective.

Ortega, F., \& Peri, G. (2013). The effect of income and immigration politics on international migration. Migration Studies, 1, 1-28.

Peters, M. E. (2014). Trade, foreign direct investment and immigration policymaking in the United States. International Organization, 68(4), 811-844.

Peters, M. E. (2015). Open trade, closed borders: Immigration policy in the era of globalization. World Politics, 67(1), 114-154.

Peters, M. E. (2017). Trade barriers: Firms, immigration, and the remaking of globalization. Princeton: Princeton University Press,

Peters, M. E. (2019). Immigration and international law. International Studies Quarterly, 63(2), 281-295.

Peters, M. E., \& Shin, A. J. (2021). Inequality and immigration policy (Working paper).

Razin, A., Sadka, E., \& Suwankiri, B. (2011). Migration and the welfare state: Political-economy policy formation. Cambridge: MIT Press.

Reichert, J. S., \& Massey, D. S. (1980). History and trends in U.S.-bound migration from a Mexican town. International Migration Review, 14(4), 475-491.

Reichert, J. S., \& Massey, D. S. (1982). Guestworker programs: Evidence from Europe and the United States and some implications for U.S. policy. Population Research and Policy Review, 1, 1-17.

Ruhs, M. (2013). The price of rights: Regulating international labor migration. Princeton; Oxford: Princeton University Press.

Shin, A. J. (2017). Tyrants and migrants: Authoritarian immigration policy. Comparative Political Studies, 50(1), 14-40.

Shin, A. J. (2019). Primary resources, secondary labor: Natural resources and immigration policy. International Studies Quarterly, 63(4), 805-818.

Singer, D. A. (2010). Migrant remittances and exchange rate regimes in the developing world. American Political Science Review, 104(2), 307-323.

Swank, Duane (2014). Electoral, legislative, and government strength of political parties by ideological group in capitalist democracies, 1950-2011. A database. http:/www.marquette.edu/polisci/documents/PARTY19502011.xls.

Taylor, A. (2008, May 25). Weak pound has Poles eyeing homeland. The Financial Times. https://www.ft.com/content/593a 9752-2a97-11dd-b40b-000077b07658.

Timmer, A. S., \& Williamson, J. G. (1998). Immigration policy prior to the 1930s: Labor markets, policy interactions, and globalization backlash. Population and Development Review, 24(4), 739-771.

Tirman, J. (2015). Dream chasers: immigration and the American backlash. Cambridge: MIT Press.

United Nations, Department of Economic and Social Affairs, Population Division (2017). International Migration Report 2017: Highlights (ST/ESA/SER.A/404). New York: United Nations Population Division.

Watts, J. R. (2002). Immigration policy and the challenge of globalization: Unions and employers in unlikely alliance. Ithaca: Cornell University ILR Press.

World Bank (2014). World development indicators.

Yang, D. (2006). Why do migrants return to poor countries? Evidence from Philippine migrants' responses to exchange rate shocks. Review of Economics and Statistics, 88(4), 715-735.

Yang, D. (2008). International migration, remittances, and household investment: Evidence from Philippine migrants' exchange rate shocks. The Economic Journal, 118, 591-630.

Yang, D., \& Choi, H. J. (2007). Are remittances insurance? Evidence from rainfall shocks in the Philippines. World Bank Economic Review, 21(2), 219-248.

Yang, D., \& Martinez, C. (2006). Remittances and poverty in migrants' home areas: Evidence from the Philippines. In International migration, remittances and the brain drain (pp. 81-121). Washington DC: World Bank.

Zolberg, A. R. (1989). The next waves: Migration theory for a changing world. International Migration Review, 23(3), 403-430.

\section{Publisher's Note}

Springer Nature remains neutral with regard to jurisdictional claims in published maps and institutional affiliations. 